PERAET 2021

International Scientific Conference «PERISHABLE AND ETERNAL: Mythologies and Social Technologies of Digital Civilization-2021»

\title{
SOCIOLOGY ON PROSPECTS OF ROBOTIZATION AND DIGITALIZATION OF RUSSIAN SOCIET
}

\author{
Marionella A. Kipriyanova (a)*, Sergey N. Smolnikov (b) \\ *Corresponding author \\ (a) Perm National Research Polytechnic University (PNRPU), Perm, Russian Federation, \\ makipr@ya.ru \\ (b) Perm National Research Polytechnic University (PNRPU), Perm, Russian Federation, \\ imperial2000@gmail.ru
}

\begin{abstract}
The research topic of the paper brings out relevant for the Russian society issue of the need to comply with humanistic principles when transitioning to a robotic and digitalized society (hereinafter RDS). Certain aspects of this issue have been reflected in Russian and foreign literature: external and internal conditions of the ongoing reforms; justification of "artificial sociality", of sociobiotechnical system (hereinafter SBT-system), of digital, social and humanitarian risks; society technicalization and the weakening of society humanization. The purpose of the study is to analyze the circumstances obstructing a successful transition to a humanized RDS. The research method is sociological, taking into account the peculiarities of a complicated research object. The study is based on the general philosophical concept of humanism, adapted to social reality; on Ulrich Beck's theory of risk society and Manuel Castells' theory of information society. Within the framework of this method, a factor analysis of the main issues of the topic has been used. Results: the logic of proving the presence of unfavorable conditions for the transition to a humanized RDS has been constructed. Among these are a global factor, excessive economization and technologization of reforms in the interests of financial groups and their political lobbies and underestimation of their social consequences; mobilization nature of reforms. Clarifying approaches to the concept of a socially equitable humanistic RDS have been proposed.
\end{abstract}




\section{Introduction}

The problem of the transition to the RDS, designated as a goal in the Strategy of the Information Society Development in the Russian Federation for 2017-2030 (Decree of the President of the Russian Federation, 2017), is understood (in it) as a transitional stage to a more advanced knowledge society based on scientific knowledge. However, this knowledge society already emerged from industrial society in the period from the 1940s to the 1960s and was associated with the scientific and technical revolution which raised the prestige of the profession of a scientist. The scientific and technical revolution was understood as the unity of social and technical progress and was enthusiastically accepted both in the West and in the USSR.

It is assumed that the $4^{\text {th }}$ technological revolution, based on artificial intelligence and autonomous robots, will allow Russia to enter a new civilizational field, accelerate social and technical progress. However, robotization and digitalization differ significantly from the technical and social progress of the past not only by the new alignment of social and class forces in the world and in Russia, but above all by expected unprecedented social risks.

Robotization and digitalization of Russian society are two related, but oppositely directed processes. If robotization is the essence of technology humanization, then digitalization is the creation of a habitat ("digital environment") for robots, since robots cannot "live" in an analog world. It is believed that the digital environment is more efficient than the social one in many parameters, and robots will be more competitive in it. The human is invited to adapt to the new environment: to move to the digital world and cyborgize, that is, to dehumanize. Unlike modernization in the past, where the technical environment was thought of as auxiliary to the social one, and the social one was based on a reliable selfreproducing biological system, the RDS is supposed to replace the external biological system and the biological basis of the human himself with a technical one. However, the technical system does not yet reproduce itself and is not capable of complete self-regulation. The supposed equalization of the rights of a robot and a human not only humanizes the former, but also dehumanizes the latter due to the subordination of both to control systems based on artificial intelligence, the "goal setting" of which is already "not clear". This poses unprecedented social risks.

We consider these risks as an important indicator of the quality of social life which presupposes a socially equitable and humanistic organization. In this regard, the research topic analyzed in the article is relevant.

\section{Problem Statement}

The research problem: The need to ensure the compliance with humanistic principles when organizing the transition of Russian society to the RDS.

In the studied literature, we have identified 5 aspects of the topic:

1) The specifics of the external conditions of social transformations taking place in Russia. The influence of the global factor, its coercive nature on the ongoing reforms have been substantiated; the spectrum of drivers of the $4^{\text {th }}$ industrial revolution (physical, digital, biological) is critically evaluated, where is essentially no place for a social driver (Burkhalter, 2017). 
2) The specifics of the domestic Russian conditions of the announced transformations. Attention is focused on the state of the economy, information environment, on the legal and social state as a guarantor of a successful transition to a humanized RDS. Based on empirical data and theoretical generalizations, the facts of the presence of symptoms of a social and humanitarian recession have been revealed (Lapin, 2016; Lapin et al., 2020).

3) Characterization of the concept of "Artificial sociality" as augmented social reality. The emergence of constructed - "highly social" risks, contributing to the forced implementation of ideas in health care, education, religion, art, as well as "digital risks" coming from economic inequality (Deursen \& Van Dijk, 2019; Kiselyova \& Castells, 2018; Kravchenko, 2019; Rezaev et al., 2020; Yanitsky, 2019) under the influence of this reality.

4) Technologization of the society as a factor of its dehumanization. The problem of compatibility of society technologization and technology humanization, the problem of the ethos of technical research as well as the problem of technical policy and the relation of technological risks to social, environmental ones have been discussed. It has been argued that the dehumanization of technology leads to a halt in the processes of its improvement and prevents the transition to a humanized RDS (Gorokhov \& Decker, 2013; Lapidus, 2019; Yanitsky, 2020).

5) On the role of sociological science in assessing the transformation processes taking place in Russia. The essence of the theories of everyday social humanism, the information society (Castells, 2021) and the risk society (Beck, 2018) has been specified; new approaches to the refined, on the basis of "artificial sociality", object of sociology, which requires a new humanistic turn in social, humanitarian and natural sciences for the transition to the RDS, have been substantiated. The significance of the predictive function of sociology has been specified (Kipriyanova \& Smolnikov, 2018a, 2018b; Kravchenko, 2015; Yanitsky, 2017).

\section{Research Questions}

When studying the research topic in a comprehensive way, several issues related to the factor analysis of the stated transformations have been identified as key issues.

1) How are the external conditions of social transformations in Russia today and in the second half of the $20^{\text {th }}$ century fundamentally different?

1.1. Stagnation of growth in labor productivity in almost all areas, except for the production of computers, in recent decades and the demand for the $4^{\text {th }}$ scientific and technological revolution by society. 1.2. Growth of surplus labor and "extreme inequality" between countries and regions, as well as within countries. 1.3. Transfer of local energy, resource, demographic crises from developed countries to "catching-up" ones with their transformation into global crises. The latter bring humanity to the limit of its possible existence. 1.4. The emergence of symptoms of the crisis of the social system and the growing dependence of society on the technical system. Initially, technology was thought of as a help in contact with the natural environment (it became the second support), which increased the stability of the system. Then it began to actively replace the natural basis (which had proven its reliability over thousands of years), which already lowers the stability of the system. Today it competes with the social environment and even builds on it. The boundaries between the social, natural and artificial environments of people are 
blurred, a highly complex SBT-system of organizing their lives appears, the management of which requires completely new knowledge and decision-making at the global and national levels. 1.5. The emergence of a networked society based on global information connections. 1.6. The problem of control over this new highly complex system through an information system and the formation of a digital environment necessary for robots to integrate into society. Robots are understood as "artificial" social agents of all social relations and a basic tool for managing a social system.

2) What is the modern Russian state and how do its internal conditions influence social transformations?

In the presence of unconditional positive trends in its development, negative trends are also noted, for example, symptoms of a humanitarian recession in society: increasing poverty of the population (over $60 \%$ ), the presence of "extreme inequality" between regions, groups, strata; violation of human rights and freedoms; reforming education, science and health care; heightened sense of social justice and values of everyday humanism among the population in the face of the consequences of social reforms (over 75\%). The current situation reflects the weakness of the welfare state, which is hardly capable of protecting the majority of Russians from the possible dehumanizing consequences of the transition to the RDS (Lapin, 2016; Lapin et al., 2020).

3) Society technologization or technology humanization? What is the role of technoscience in the perspective of the transition to the RDS?

If technology was initially assessed according to its usefulness for society, then in terms of scientism applied to it (when scientists practically turned into priests), there was a sacralization of technology - any technical object began to acquire the properties of scientificity and social progress. This was facilitated by the policy of its ideologization in the interests of the ruling social groups who saw a reliable source of growth in profit and power in it. The priority of the rate of technicalization of society has weakened attention to the processes of its humanization. The "alienation" of the creators of technology from serving social progress has increased. However, robotic technology, as a symbiosis of the SBT-system based on artificial intelligence, cannot develop without communication with society, therefore the political task of society and government is to converge technical research with humanitarian and natural scientific research. This is possible only on the basis of the principles of humanization of technology. There is simply no other choice for a human with the prospects of the transition to the RDS.

\section{Purpose of the Study}

Purpose of the study: to analyze the circumstances that impede the successful transition to a humanized RDS.

\section{Research Methods}

The study of the prospects of the RDS is based on the theory of humanism, the risk society theory (Beck, 2018) and the information society theory (Castels, 2021). This is due to the refinement and complication of the research object; the introduction of modern elements into its traditional object, which is the social life of society. These elements include "artificial sociality" and the SBT-system 
(Kravchenko, 2015; Rezaev et al., 2020). Under the influence of the agents of artificial sociality, endowed with imitative thinking, inherently new social risks began to enter social life. In order to study them by European and Russian sociologists, the concept of a global risk society has been developed. In sociology, there has been a new humanistic turn based on the principles of socio-technical and environmental justice. The latter has been used since the second half of the $20^{\text {th }}$ century and is associated with the solution of environmental problems studied at the local level: social communities, groups and individuals.

In the developed concept of everyday social humanism, taking into account the significant complication of the object under study, a supra-disciplinary approach that combines the efforts of social, humanitarian and natural sciences in solving social problems that are urgent for society has been used. The introduction of all the specifying points into the method of sociology has been undoubtedly facilitated by its inherent predictive function.

\section{Findings}

The results of the work are reflected in the factor analysis of the research topic. They correspond to the stated purpose of the study - to identify the circumstances that impede Russia's successful transition to a humanized RDS. The following key issues of the topic have been analyzed: the influence of global factors, the state of the welfare state and technical policy in the Russian Federation. We have built our own logic of proving the presence of unfavorable conditions for the transition to a humanized RDS.

The starting factor in this logic is the slowdown in the growth of labor productivity (except for the production of computers) since the $70 \mathrm{~s}$ of the $20^{\text {th }}$ century and the actual cessation of the development of concepts of social and technical progress. The economies of developed countries have entered a recession since that time. At the same time, the standard of living is practically not growing, and social development has stalled. Hence the hopes for the $4^{\text {th }}$ technological revolution which requires long-term investments in fundamental research of breakthrough technologies. Financial capitalism, in contrast to industrial capitalism, is focused on ultra-fast profits and profits without production. Post-industrialism has turned into deindustrialization.

The permanent nature of economic and environmental crises exposes the limits of the existence of financial capitalism and the very human species in nature.

The concept of the scientific and technological revolution gave rise to the sacralization of technology as a savior from all crises and a guarantor of the survival of mankind. Technoscience became a "sacred science", and its priests declared themselves technocrats. This has been facilitated by the policy of ideologizing and economizing technology, which meets the interests primarily of the dominant economic groups and the power structures lobbying them. Faith in reason has gradually narrowed down to faith in progress, then to faith in science, reduced to faith in physics, and that - in its objectified product - in technology. Thus, humanism has been transformed into technicism. The technical environment has begun to consume the rest of human environments and is threatening to become pervasive. But being initially projective, it comes into conflict with a person's free will and his right to self-development. 
The emergence of robotic technology with artificial intelligence accelerates the formation of a highly complex SBT-system and an information network society, in which the struggle for power over this system begins. Whoever gain control of it will control the fate of humanity as a whole.

Russia is at the center of these events and obeys their logic. The dismantling of its former social system and the reduction of social spending are manifested in a socio-humanitarian recession. At the same time, using its civilizational achievements, it is trying to adequately fit into the general planetary SBT-system, relying on the development of breakthrough - nature-like - technologies that can stop the destruction of natural resources, restore the balance between nature and people. The creation of such technologies is based on the convergence of humanities, social and natural sciences. In this, in our opinion, one can see its desire for a humanized future.

However, disruptive technologies and the mobilization nature of their implementation lead us to the principle "the end justifies the means", which contradicts the main goal — the transition to a humanized RDS. The massive introduction of digital innovations, instantly scalable to supra-national levels, is turning the lives of current generations into a multitude of non-voluntary experiments. In addition, the reforms are predominantly economic in nature. Their main agents are financial groups and lobbies in power structures. It is logical that these are the groups that benefit from the reforms. We see a threat to the humanism of the RDS in their readiness for international digital integration without preconditions.

Thus, the results of the work have an independent nature and represent a certain novelty.

\section{Conclusion}

In conclusion, we would like to note that the research topic addresses the urgent problem for society - the need to comply with humanistic principles when organizing the transition of Russia to the RDS.

The studied literature and published sociological data reflect the serious concern of the scientific community and other social institutions with the tendencies of dehumanization (declared as optimization) in the social and humanitarian sphere and their possible deepening caused by the transition to the RDS. Our research findings also support these conclusions. Russia, as a part of the world system, cannot distance itself from "global risks". However, the primary task of the sovereign state is to preserve the social security of Russians and to strengthen the welfare state. In this regard, the task of sociology as a fundamental science of society, which studies its natural social formations (based on a self-reproducing biological basis), is to actualize its predictive function. We offer:

1.In order to guarantee the survival of different groups of society in the conditions of their adaptation to a highly complex SBT-system, to legislatively consolidate the role of the technical only as a factor that complements the biological;

2.To legally assign to the state the function of creating "backup copies of the cultural code" by analogy with self-reproducing biological reserves;

3.To legally establish a preliminary (even at the design stage) socio-ecological and biological expertise of equipment and technologies; 
4.To legally prohibit the nationwide introduction of new technologies without testing them at the local level;

5.Taking into account the interdisciplinary nature of the research object, to develop a supradisciplinary scientific approach to the study of the SBT-system based on the category "Social Consequences";

6.Provide a humanistic (in service of people) turn in the research of all sciences.

The above recommendations can be implemented only if a new, equally comprehensive and inherently humanistic SBT-policy is carried out in society.

\section{References}

Beck, U. (2018). The cosmopolitan society and its enemies. In L. Tomasi (Ed.), New Horizons in Sociological Theory and Research: The Frontiers of Sociology at the Beginning of the TwentyFirst Century (pp. 181-202). Ashgate Publishing.

Burkhalter, L., \& Castells, M. (2017). Toward a new urban paradigm. In T. Haas \& H. Westlund (Eds.), The Post-Urban World: Emergent Transformation of Cities and Regions in the Innovative Global Economy (pp. 225-248). Routledge.

Castells, M. (2021). From cities to networks: Power rules. Journal of Classical Sociology. https://doi.org/10.1177/1468795X211022054

Decree of the President of the Russian Federation dated 09.05.2017 No. 203 «O Strategii razvitiia informatsionnogo obshchestva v Rossiiskoi Federatsii na 2017-2030 gody" ["On the Strategy for the Development of the Information Society in the Russian Federation for 2017-2030"]. http://www.kremlin.ru/acts/bank/41919

Deursen, A. J. A. M., \& Van Dijk, J. A. G. M. (2019). The first-level digital divide shifts from inequalities in physical access to inequalities in material access. New Media \& Society, 21, 354375.

Gorokhov, V. G., \& Decker, M. (2013). Tekhnologicheskie riski kak sotsial'naia problema pri razrabotke i vnedrenii intellektual'nykh avtonomnykh robotov [Technological risks as a social problem in the development and implementation of intelligent autonomous robots]. In D. I. Dubrovskiy (Ed.), Global'noe budushchee 2045. Konvergentnye tekhnologii (NBIKS) $i$ transgumanisticheskaia evoliutsiia [The Global Future 2045. Convergent Technologies and Transhumanistic Evolution]. (pp. 82-93). MBA.

Kipriyanova, M. A., \& Smolnikov, S. N. (2018a). Ekologicheskaia spravedlivost' kak sotsiologicheskaia kategoriia [Environmental justice as a sociological category]. Vestnik PNIPU. Sotsial'noekonomicheskie nauki [PNIPU Sociology and Economics Bulletin], 3, 83-94.

Kipriyanova, M. A., \& Smolnikov, S. N. (2018b). Sotsiologicheskii analiz problemy ekologicheskoi spravedlivosti [Sociological analysis of the problem of ecological justice]. Istoricheskaia $i$ sotsial'no-obrazovatel'naia mysl', 10(6-1), 117-126.

Kiselyova, E., \& Castells, M. (2018). Russia in the Information Age. In V. E. Bonnell \& G. W. Breslauer (Eds.), Russia in the New Century: Stability or Disorder? (pp. 126-157). Routledge.

Kravchenko, S. A. (2015). Sotsiologicheskoe znanie cherez prizmu "strely vremeni": vostrebovannost' gumanisticheskogo povorota [Sociological knowledge through the prism of 'Time Arrow'. The need of a humanistic Turn]. MGIMO-Universitet.

Kravchenko, S. A. (2019). Tsifrovye riski, metamorfozy i tsentrobezhnye tendentsii v molodezhnoi srede [Digital risks, metamorphoses and centrifugal trends among the young people]. Sotsiologicheskie issledovaniya, 10, 48-57. https://doi.org/10.31857/S013216250006186-7

Lapidus, L. V. (2019). Rabota dlia robota [Work for a Robot]. V mire nauki (Scientific American), 7, 4855. 
Lapin, N. I. (2016). Simptomy sotsiogumanitarnoi retsessii i sposoby ukrepleniia sotsial'nogo gosudarstva [Symptoms of socio-humanistic recession and ways to strengthen the social state]. Obshchestvennye nauki i sovremennost' [Social Sciences and Contemporary World], 5, 19-29.

Lapin, N. I., Ilyin, V. A., \& Morev, M. V. (2020). Ekstremal'nye neravenstva i sotsial'noe gosudarstvo [Extreme inequalities and the social state] (part 2). Sotsiologicheskie issledovaniya, 2, 20-30. https://doi.org/10.31857/S013216250008491-3

Rezaev, A. V., Starikov, V. S., \& Tregubova, N. D. (2020). Sotsiologiia v epokhu" iskusstvennoi sotsial'nosti": poisk novykh osnovanii [Sociology in the age of 'artificial sociality': search of new bases]. Sotsiologicheskie issledovaniya, 2, 3-12. https://doi.org/10.31857/S013216250008489-0

Yanitsky, O. (2017). Organic Modernization vs. Information Archaization. Social Sciences, 48, 111-122.

Yanitsky, O. (2019). Vyzovy i riski globalizatsii. Sem' tezisov [Challenges and risks of globalization. $\begin{array}{lllll}\text { seven theses]. } & \text { Sotsiologicheskie issledovaniya, }\end{array}$ https://doi.org/10.31857/S013216250003745-2

Yanitsky, O. (2020). Tekhnonauka: prirodnye, sotsial'nye i tekhnologicheskie posledstviia [Technoscience: natural, social, and technological consequences]. Sotsiologicheskie issledovaniya, 6, 145-154. https://doi.org/10.31857/S013216250009382-3 